\title{
Effect of Stress Coping Skills Training on the Job Stress of Iranian Nurses: A Systematic Review and Meta-Analysis
}

Asghari JafarAbadi. $\mathrm{M}^{1}$

Karimi. $L^{2}$

Rahimi Bashar. F3

Vahedian Azimi. A4

${ }^{*}$ Khalil. R5

1- Ph.D. of Biostatistics, Professor, Statistics and Epidemiology, Road Traffic Injury Research Center, Tabriz University of Medical Sciences, Tabriz, Iran.

2- Ph.D. of Reproductive Health, Assistant Professor, Behavioral Sciences Research Center, Life Style Institute, Faculty of Nursing, Baqiyatallah University of Medical Sciences, Tehran, Iran.

3- Intensivist, Associate Professor, Anesthesia and Critical Care Department, Hamadan University of Medical Sciences, Hamadan, Iran.

4- Ph.D. of Nursing Education, Trauma Research Center, Faculty of Nursing, Baqiyatallah University of Medical Sciences, Tehran, Iran.

5- ( ${ }^{*}$ Corresponding Author) Ph.D. of Nursing Education, Assistant Professor, Behavioral Sciences Research Center, Life Style Institute, Faculty of Nursing, Baqiyatallah University of Medical Sciences, Tehran, Iran.

Email: khalili1120@gmail.com

\section{Abstract}

Introduction: Nurses are more susceptible to stress due because of their career nature. However, stress management is one of the components of health education..

Objective: The aim of the present systematic review and meta-analysis was to examine the effect of teaching the stress coping skills on occupational stress in Iranian nurses.

Material and Methods: The current study was systematic review and meta-analysis performed until the early of April 2019. By searching phrases of "job stress, stress, nursing and nurse" in Persian databases such as SID, Mag Iran, Iran Medex, Iran Doc, and English equivalents including Scopus, Pub med, Web-of-science, Proquest, and Science direct, all relevant studies were extracted by using Boolean "AND" and "OR". Google Scholar search engine was searched in both Persian and English. The methodological quality of the papers was examined using the Cochrane-risk-of-bias tool. Data were analyzed by the random effects model and heterogeneity by I 2 index using STATA 11.

Results: Of a total of 1069 extracted studies, six studies have investigated the effect of stress coping skill training on occupational stress in nurses. The joint effect size $(-1.77)$ indicated a reduction in the effect of interventions on stress, but the heterogeneity was very high (I2 $=3.85 \%$ ). The results of meta-regression showed that none of the variables in the study such as publication year, sample size, and male to female ratio were heterogeneous. To control heterogeneity, it reached zero (I2 $=0.00 \%$ ) by the elimination of cast-away studies and the results showed that the interventions significantly reduced stress (Effect size: $-0.57(-0.81-0.34) \mathrm{P}<0.001)$.

Discussion and Conclusion: Regarding the effect of training the stress coping skills on mitigating stressin nurses' job it is recommended to implement interventional educations to reduce the stress of nurses.

Keywords: Coping Skills, Meta-Analysis, Nurses, Stress, Systematic Review. 


\section{تأثير آموزش مهارتهاى مقابله با استر بر استرس شغلى برستاران ايرانى: يك مرور نظام مند و فرا تحليل}

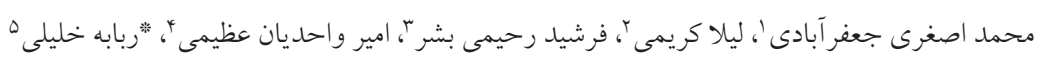

جكيده مقدمه: پِرستاران به دليل شرايط شغلىشان بيشتر در معرض استرس قرار دارند. از آنجا كه يكى از اركان آموزش سلامت،

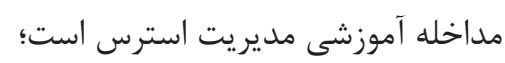
هدف: هدف از مرور نظام مند و فرا تحليل حاضر بررسى مدأثير آموزش مهارتهاتى مقابله با استرس بر استرس شغلى

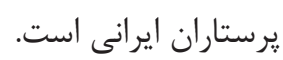

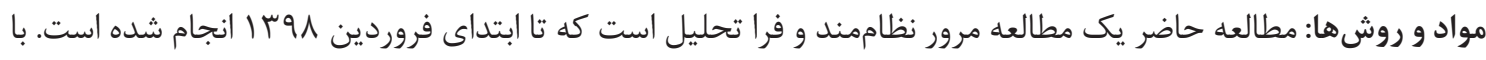
جستجوى عبارات استرس شغلى، استرس، يرستارى و يرستار در پإيخاههاى فارسى SID، MagIran، و IranMedex،

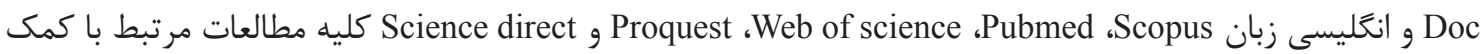
عملكَرهاى AND و OR استخراج شدند. موتور جستجوى گو گَل اسكولار به صورت فارسى و انغليسى بررسى شد. كيفيت روششناسى مقالات با استفاده از ابزار خطر تورش كوكران بررسى شد. جهت تحليل از مدل اثرات تصادفى استفاده و

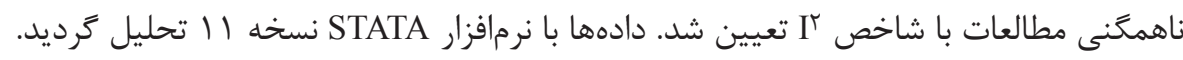

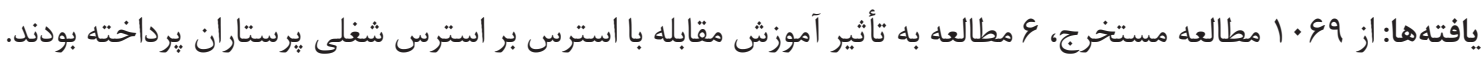

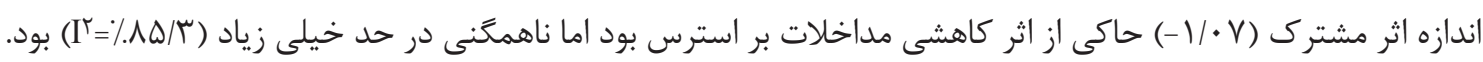

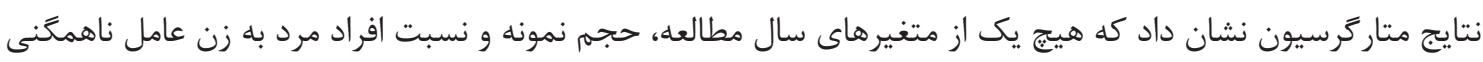

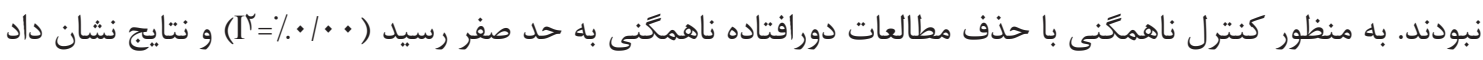

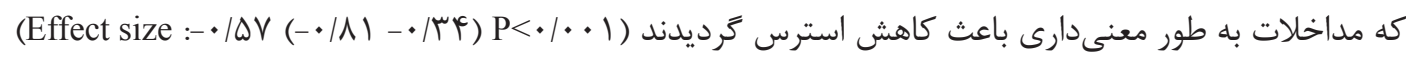

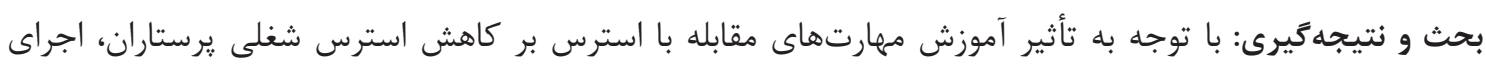

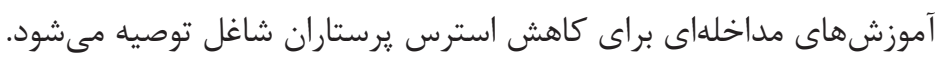

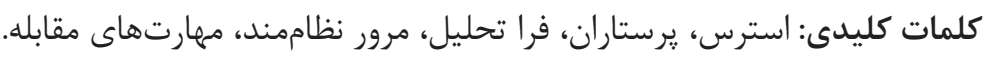

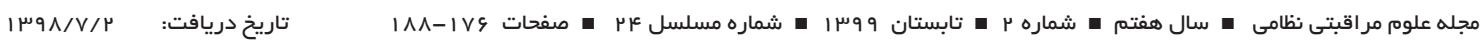

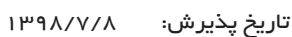

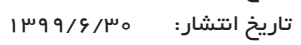

قرن بيستم ناميد و در طى سالهاى اخير سازمان جهانى بهداشت مقدمه

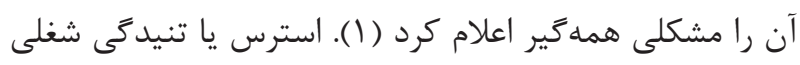
استرس شغلى امروزه به مسئلهاى شايع و برهزينه در محيطهاى

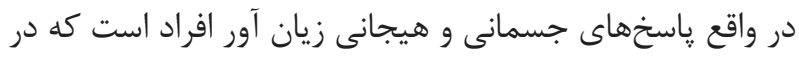
كارى تبديل شده است به طورى كه سازمان ملل آن را بيمارى

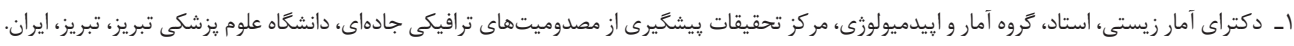

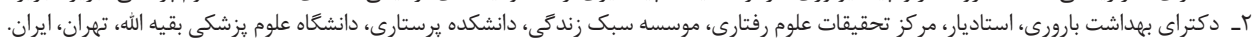

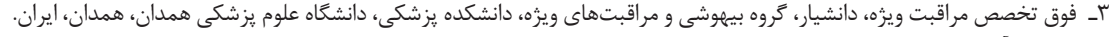

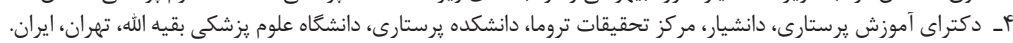

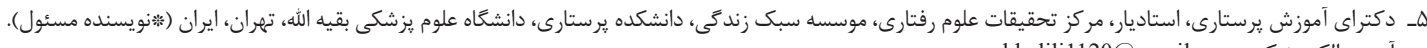
آدرس الكترونيكى: khalili1120@gmail.com 
دارند و از سوى ديخر با توجه به تأثيرات منفى استرس بر زندگى

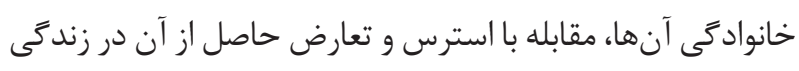

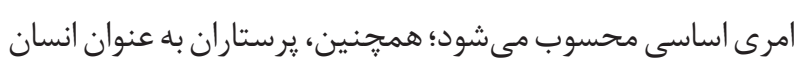

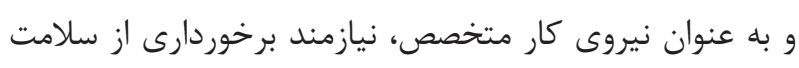

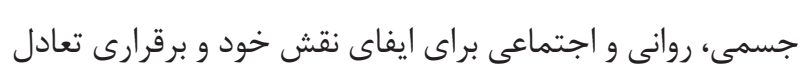

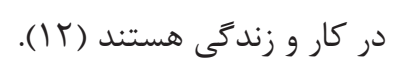

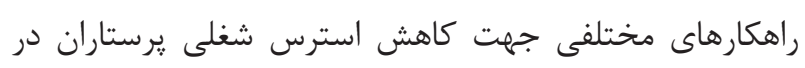

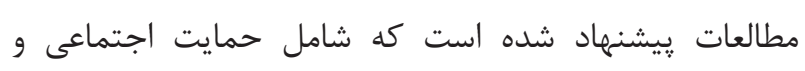
مديريتى، آموزش مهارتهاى مقابله استرس و ارتقاى بهداشت

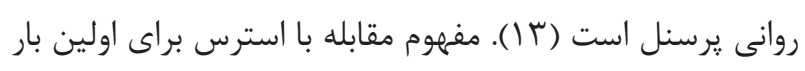

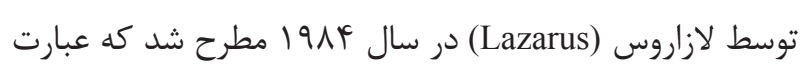

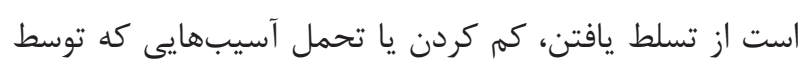

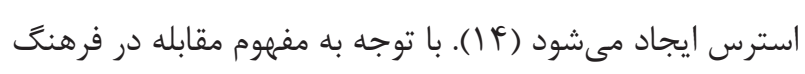

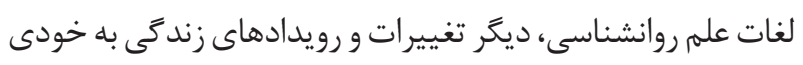

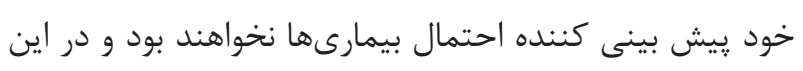
زمينه فقط به عنوان شرط لازم عمل خواهند كرد؛ زيرا در كنار

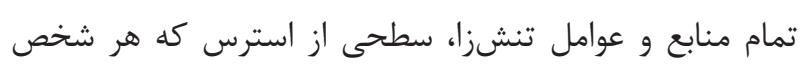
تجربه مى كند به ميزان زيادى به توانايى مقابله، نحوه ادراك و و

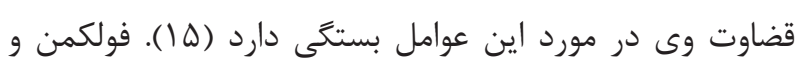
لازاروس شيوههاى مختلف مقابله با استرس را مورد بررسى قرار دادند به طورى كه بر اساس اين نظريه دو مقابله اصلى مسئله مختله مدابله

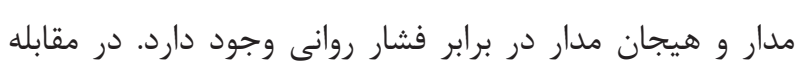

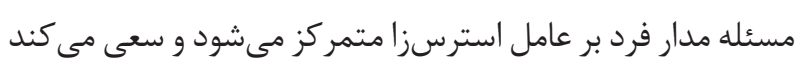

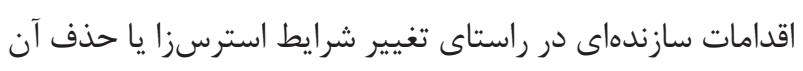

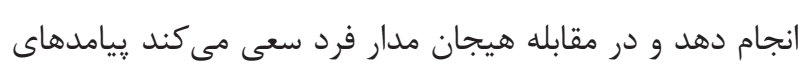

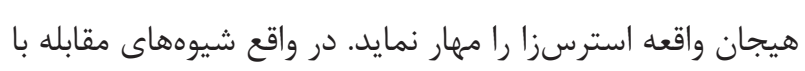

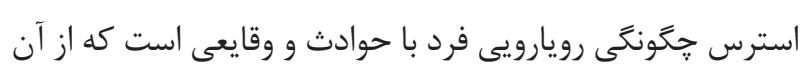

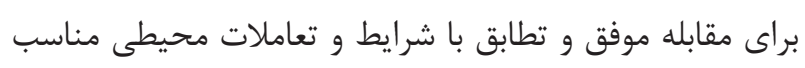

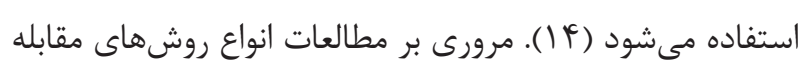

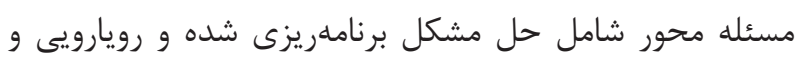

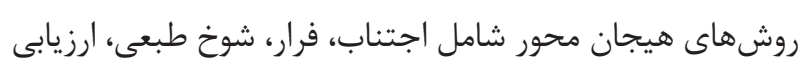
مجدد مثبت، جستجوى حمايت اجتماعى، حواس يرتى، انكار و

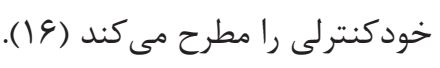
از آنجا كه استرس كارى از مشكلات اصلى يرستاران است كه مه (1).
شرايط يا مواقعى كه نيازهاى شغلى، توانيى ها، منابع و يا نيازهاى

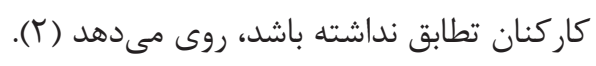

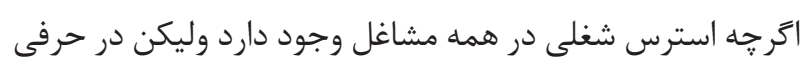

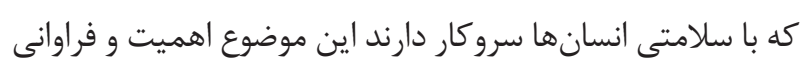

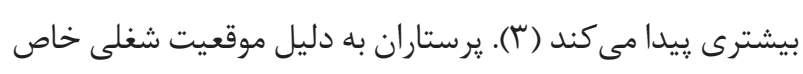

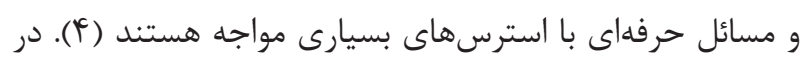

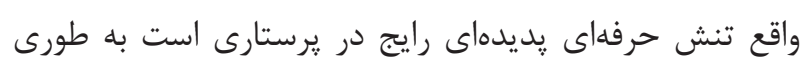

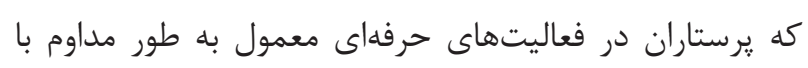

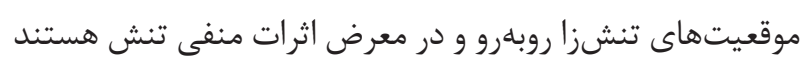

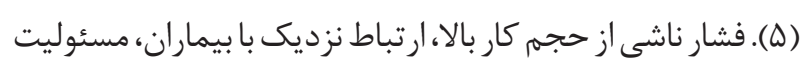

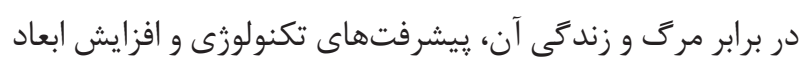

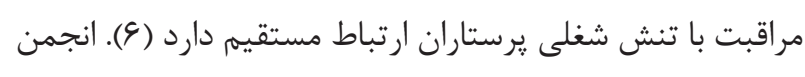

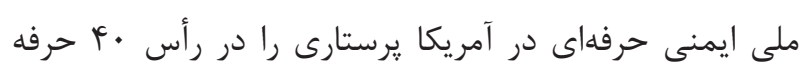

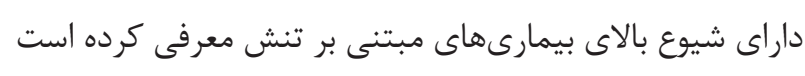

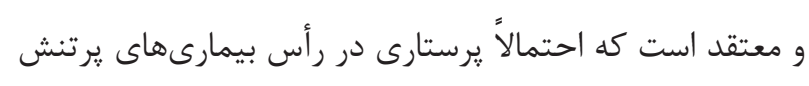
بهداشتى قرار دارد (V). در كشور ايران نيز •م درصد شاغلين

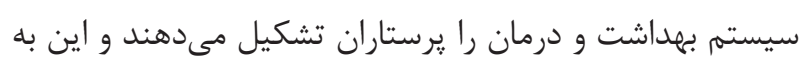
طورى است كه در اين سيستم عمده كارها به عهده آنها كذاشته

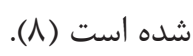

از آنجا كه استرس شغلى يكى از عوامل اساسى كاهش بهرهورى

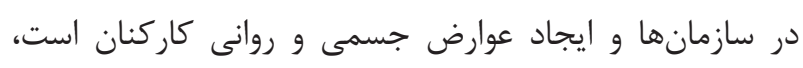
مىتواند منجر به ترك شغل، اختلال سلامتى، نارضايتى شغلى، وانى

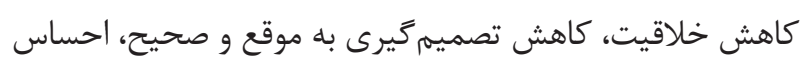

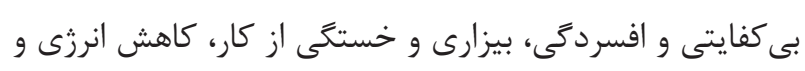

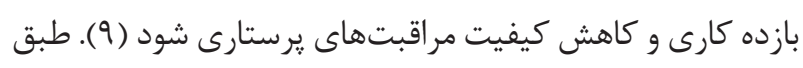

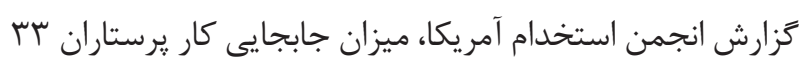

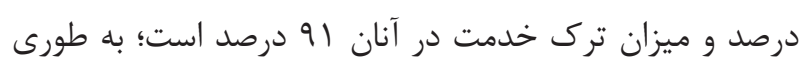

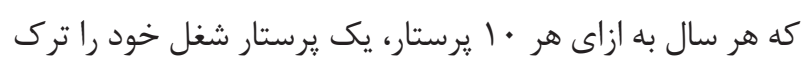

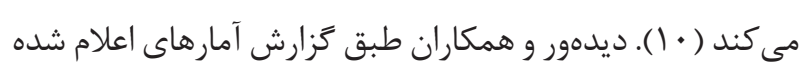
از سوى نظام يرستارى كشور بيان مى كنند كه ه ل درصد يرستاران

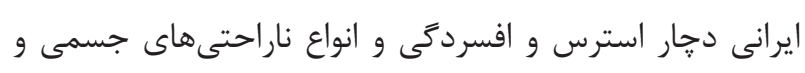
روحى هستند (11). با استناد به مطالعات صورت كرفته، يرستاران به دليل شرايط (1). شغلى بيشتر در معرض استرس كارى و تعارض كار زندگى قرار 
اجراى مداخله براى آنها صورت نكرفته باشد و O: استرس شغلى. جامعه يزوهش كليه مقالات داخلى و خارجى بود كه به تأثير

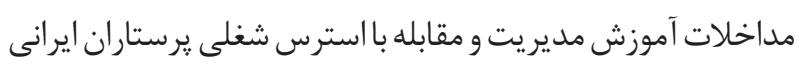

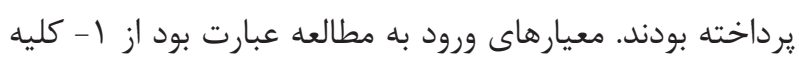

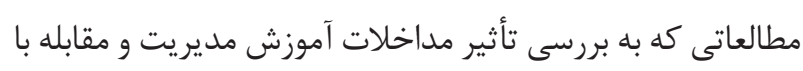

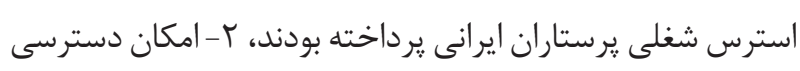

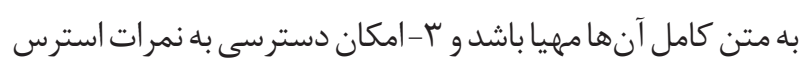
شغلى براى ورود به تحليل بود. معيار خروج از مطالعه استفاده از

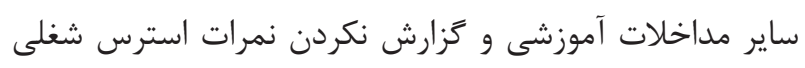
براى ورود به تحليل بود و همجنين انجام مطالعه در ساير كشورها

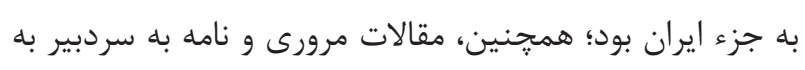

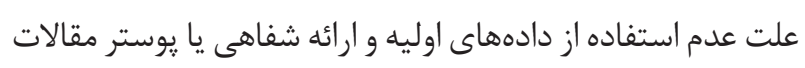

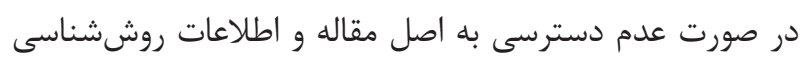

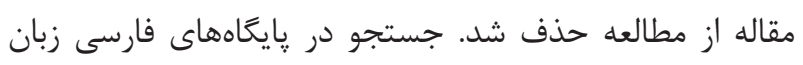
اطلاعات علمى جهاد دانشكاهى، اطلاعات نشريات كشور، سامانه

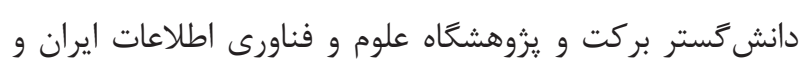
انغليسى زبان Science PubMed ،Web of Science Scopus Google Scholar و انجام يافت. موتور جستجوى Proquest به صورت انخليسى و فارسى به جهت افزايش غناى تعداد مقالات بازيابى شده جستجو شد. براى يافتن مقالات مرتبط در يايعاههاى

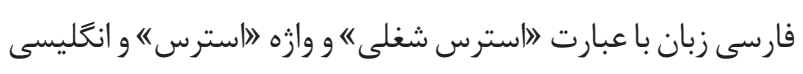

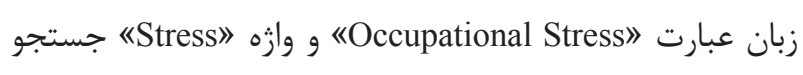

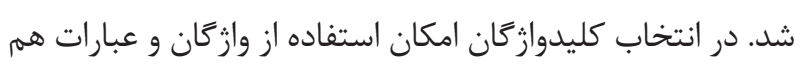

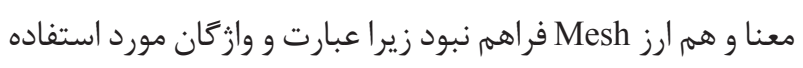
هم معنا و هم ارز ندارند (نمودار ()).

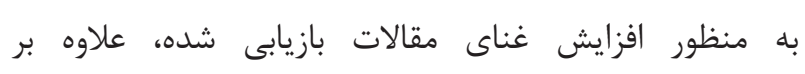

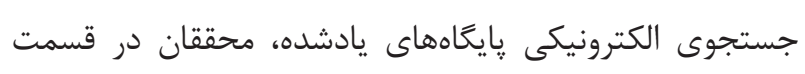

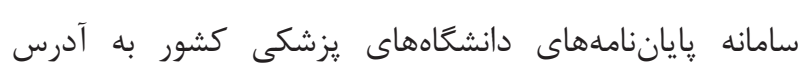
thesis.reserch.ac.ir كه همخوان با اهداف و معيارهاى ورود به مطالعه حاضر بود، وارد

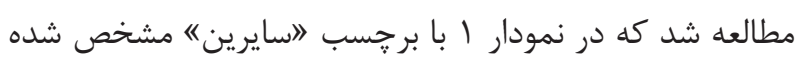

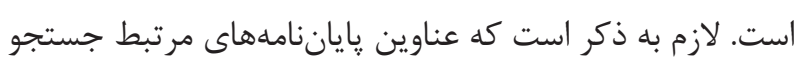

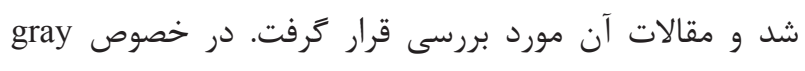
literature
تأثير زيادى بر عملكرد حرفهاى و زندكى شخصى آنها كذاشته و

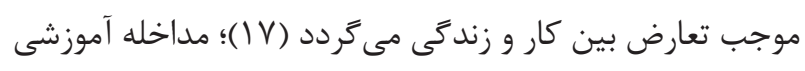

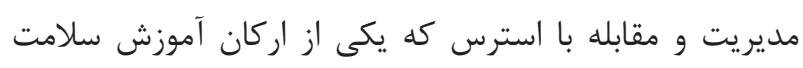

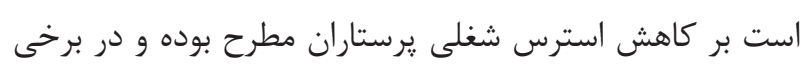

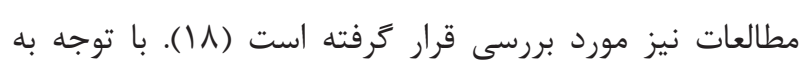

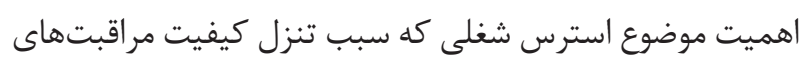
يرستارى، افزايش هزينههاى درمانى كاركنان و افزايش غيبت از ماز

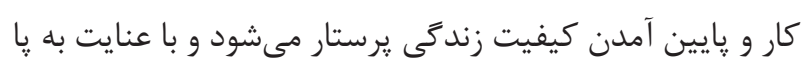
بر جايى و تداوم مشكل علىرغم استفاده از مداخلات آموزشى مقابله

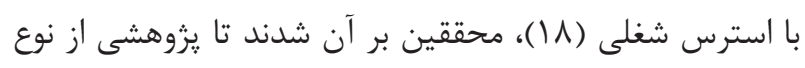

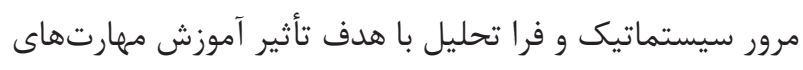
مقابله با استرس بر استرس شغلى يرستاران ايرانى انجام دهند.

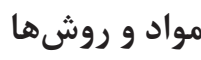

مطالعه حاضر يك مطالعه مرور سيستماتيك و فرا تحليل است رونا

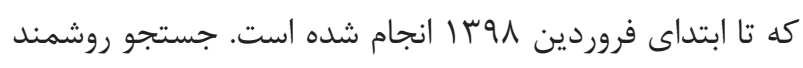
براى بازيابى مطالعات خايى و غير جايى مرتبط با مداخلات آموزش مديريت و مقابله با استرس شغلى يرستاران ايرانى انجام يافت.

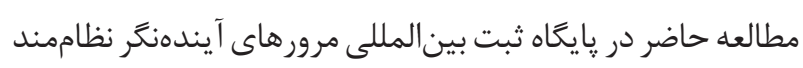
(The International Prospective Register of Systematic Reviews (PEROSPERO))

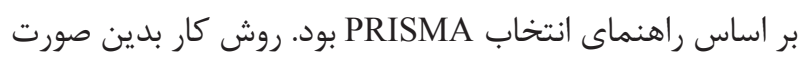
بود كه ابتدا مطالعات از بايكاههاى مختلف وارد نرم افزار مديريت

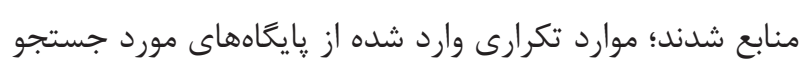

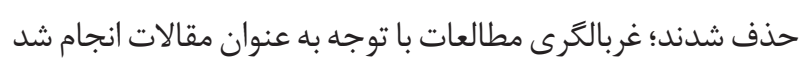

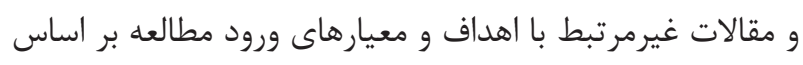

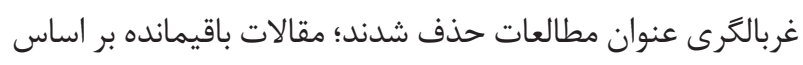

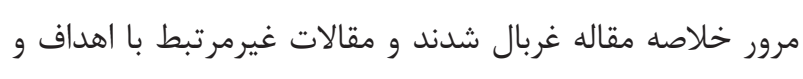

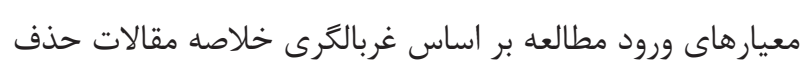
شدند؛ متن كامل مقالات باقيمانده به دقت بررسى شد و و در نهايت معايت

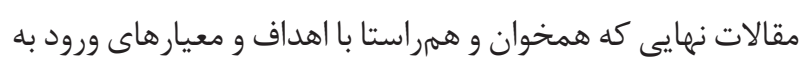

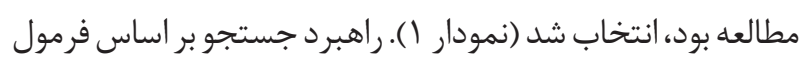
PICO

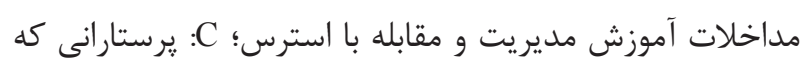




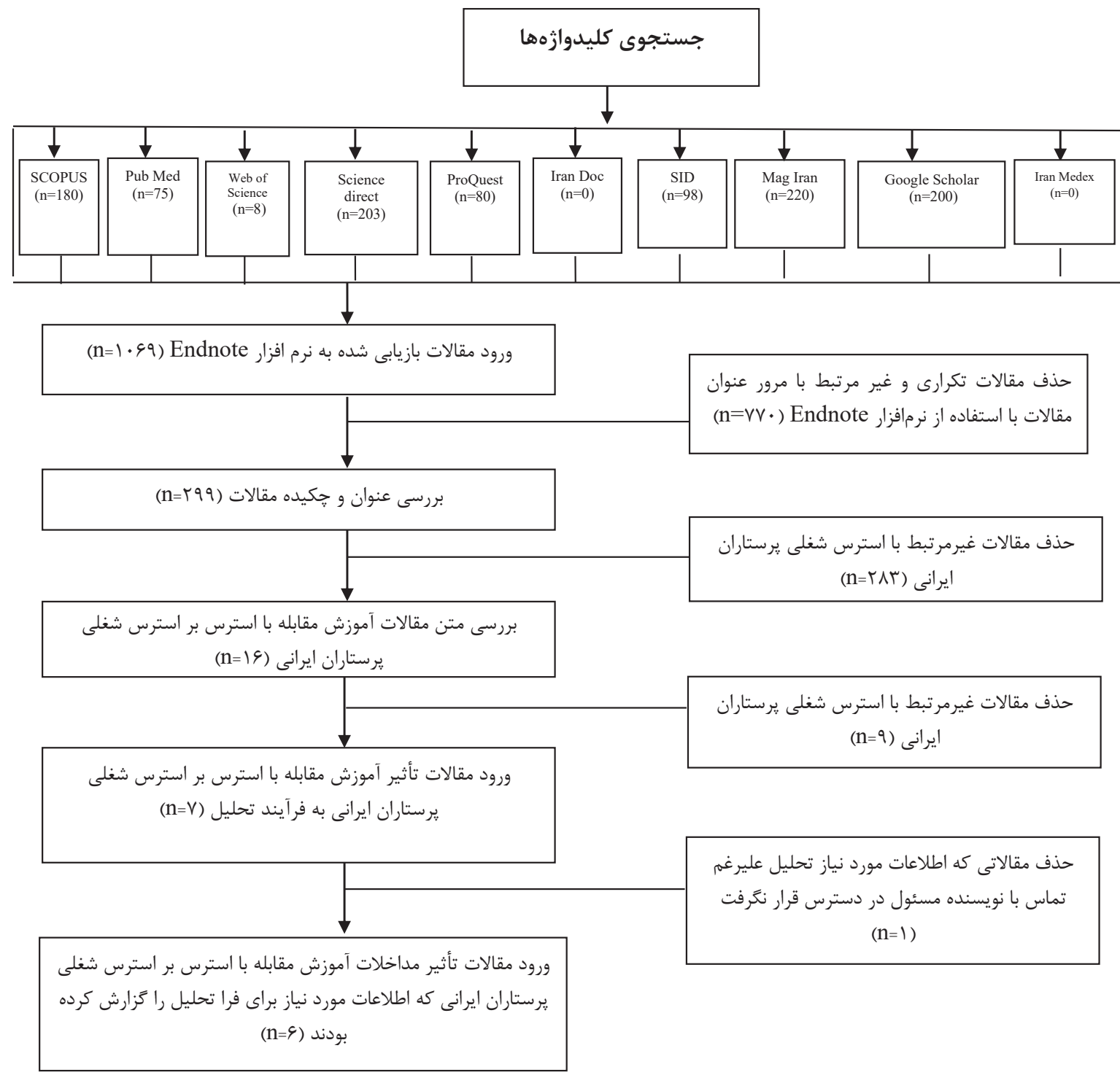

\section{نمودار 1- روند ورود مطالعات به يثوهش}

اندنوت Endnote-Thomson Reuters, XV.ఎ, Bld (ه (qr) طبق جدول ذيل استفاده شد (جدول ()). يس از جستجوى اوليه مطالعات بازيابى شده، مطالعات با توجه به معيارهاى ورود انتخاب شدند تا به مطالعاتى رسيديم كه شرايط ورود به مطالعه حاضر را داشتند. در فر آيند انتخاب مطالعات، صرفاً مطالعاتى وارد شدند كه به بررسى تأثير آموزش مهارتهاى مقابله با استرس بر استرس شغلى يرستاران ڤرداخته بودند. كيفيت مقالات نهايى شده توسط سه محقق ارزياب با تجربه در زمينه يزوهشهاى مرور سيستماتيك و فرا تحليل به طور جداعانه مورد بررسى قرار گرفت. سيس در يك جلسه مشترى نتايج به بحث و بررسى كذاشته شد و در مواردى كه اختلاف
قرار مى گرفتند و مطالعاتى نظير كنفرانسها شامل موارد ضرورى نبودند، وارد نشدند اما يايان نامهها به صورت دستى و همجنين در پايگاه Proquest مورد جستجو قرار گرفتند. در خصوص پايعاه مطالعاتى كه در اين پايڤاه بودند تنها خلاصه مقاله بوده و IRCT مقاله جاب شده آن در صورتى كه واجد معيارهاى ورود به مطالعه بود، وارد مطالعه شد. جهت اطمينان از بازيابى كليه مقالات قابل استفاده فهرست منابع مقالات بازيابى شده نيز مورد جستجو قرار گرفت. تعداد مقالات مورد نياز براى مرور كه معيارى براى صحت و دقت فرمول جستجو است، (Number need to read (NNR)) در مطالعه حاضر 1 است (نمودار ( ). به منظور سازماندهى مطالعات از نرمافزار مديريت منابع اطلاعاتى 
جدول ا- كليد وازهها و پايگًاههايى جستجوى دادههاى مطالعه

\begin{tabular}{|c|c|}
\hline يايگًاه & كليد وازگًان مورد استفاده جهت جستجو \\
\hline Scopus & $\begin{array}{l}\text { ( TITLE-ABS-KEY ( "stress" ) AND TITLE-ABS-KEY ( "nurse" OR "nursing" ) } \\
\text { AND TITLE-ABS-KEY ( "Iran" )); }\end{array}$ \\
\hline Pubmed & $\begin{array}{l}\text { (("stress"[Title/Abstract]) AND ("nurse"[Title/Abstract] OR } \\
\text { "nursing"[Title/Abstract])) AND "Iran"[Title/Abstract]; }\end{array}$ \\
\hline Web of science & TOPIC: ("stress") AND TOPIC: ("nurse" OR "nursing") AND TOPIC: ("Iran") \\
\hline Google scholar & $\begin{array}{l}\text { (TITLE-ABS-KEY ("stress") AND TITLE-ABS-KEY ("nurse" OR "nursing") AND } \\
\text { TITLE-ABS-KEY ("Iran") or (("stress"[Title/Abstract]) AND } \\
\text { ("nurse"[Title/Abstract] OR "nursing"[Title/Abstract])) AND "Iran"[Title/Abstract]. }\end{array}$ \\
\hline Iran Medex, Iran Doc, SID, Mag Iran & استرس شغلى، يرستار و استرس \\
\hline
\end{tabular}

درصدى آنها با استفاده از مدل با اثر تصادفى Dair Simonian and Forest Plot دَزارش گرديد. براى بررسى علل ناهمَّنى Laird از متار گرسيون Meta regression نيز استفاده شد؛ در اين تحليل اندازه اثر هر مطالعه بر روى متغيرهاى موجود شامل سال انجام مطالعه، حجم نمونه در هر مطالعه و همجنين نسبت تعداد مردان به زنان در هر مطالعه ركرسيون شد. در صورت معنىدار شدن در اين تحليل، متغيرها به عنوان عامل ناهمخنى تلقى مىشوند. براى بررسى اريبى (Bias) انتشار از نمودار قيفى و آزمونهاى بَ (Egger) و ايخر) (Beg) استفاده شد. پخش متقارن نقاط در نمودار قيفى كه مقدار اندازه اثر در مقابل خطاى معيار آن رسم مىشود و نتايج غير معنى دار آزمونهاى Beg و Egger نشان دهنده عدم اريبى در انتشار است. سطح معنىدارى در تمام موارد كمتر از ه • | • • در نظر ₹رفته شد.

\section{يافتهها}

حاصل جستجوى اوليه متون 99.1 مقاله بود كه با توجه به راهنماى انتخاب PRISMA، اين تعداد مقاله بازيابى شده به

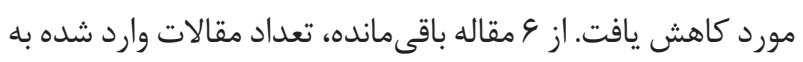

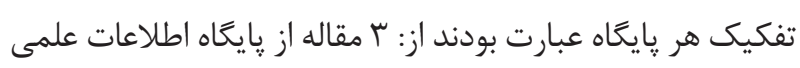
جهاد دانشگاهى، ب مقاله از يايگًاه اطلاعات نشريات كشور، ( مقاله از پايگاه Pubmed. مطالعات نهايى شده از حيث نويسند انجام، نوع يروهش به همراه تعداد گروههاى مورد مطالعه، هدف از اجراى يزوهش، روش نمونه از حيث تعداد افراد و نوع بيمارى، روش جمع آورى اطلاعات و ندون نتيجه كيرى نهايى اجراى مدل طبقهبندى و مرور شدند (جدول ؟). كيفيت جاب مقالات براى ورود به فرا تحليل توسط مقياس كوكران
نظر وجود داشت، بحث و بررسى تا حدى ادامه يافت كه توافق نهايى بين سه محقق ارزياب حاصل شد. محقق به منظور بررسى كيفيت مقالات از مقياس خطر تورش كوكران Cochrane Risk of

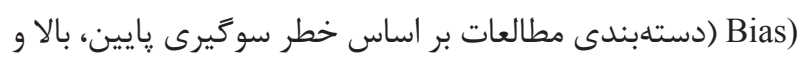
نامشخص) استفاده نمود. مقياس خطر تورش كو كران مقياسى براى بررسى ميزان تورش در مطالعات مداخلهاى است. در اين مقياس، تورش به عنوان قضاوت در مورد انتخاب (شامل توليد توالى تصادفى و ينهانسازى تصادفى)، عملكرد (شامل كورسازى شركت كنند و يرسنل درمانى مراقبتى و كورسازى ارزيابى ييامد مورد بررسى)، ريزش، ززارش و ساير موارد مهلم ديخر به صورت زياد (High)، كم و نامشخص (Unclear) ارزيابى مىشود (1 (1). STATA ه (StataCorp, College براى تحليل دادهها از نرم افزار استفاده شد. فرا تحليل با اثرات تصادفى Station, Texas, USA) براى تركيب نتايج مطالعات و محاسبه اندازه اثر مشترك استفاده گرديد. براى اين منظور با توجه به دادههاى موجود، از هر مطالعه، ميانگين و انحراف معيار اختلاف اندازهزيرىهاى قبل و بعد مداخله محاسبه و وارد گرديد. براى بررسى ناهمًَنى در مطالعات از آزمون كاى دو به طور متداول استفاده مىشود ولى به دليل توان پايين

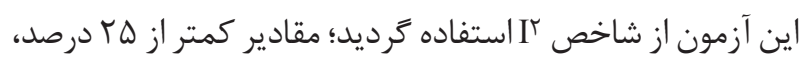

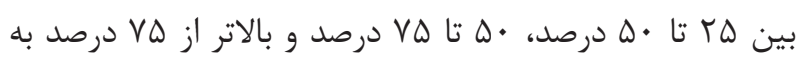
ترتيب همًَنى در حد كم، متوسط، زياد و خيلى زياد را نشان مى دهد (9 (1). در اين مطالعه با توجه به حضور ناهمخنى در حد خيلى زياد از تحليل حساسيت براى يافتن مطالعاتى استفاده شد كه ناهمخنى ايجاد كرده بودند. تحليل هاى مجدد بدون حضور اين مطالعات تكرار گرديد كه با توجه به سطح ناهمگَنى قابل قبول در

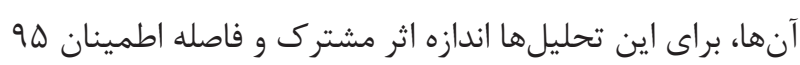


جدول r- مقالات واجد شرايط ورود به مطالعه سيستماتيك و فرا تحليل

\begin{tabular}{|c|c|c|c|c|c|c|}
\hline نتيجه گيرى & روش جمع آورى & ويزگكى نمونهها & نمونه رَيرى & هدف از اجراى مطالعه & يزوهش & 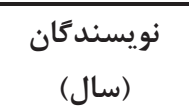 \\
\hline 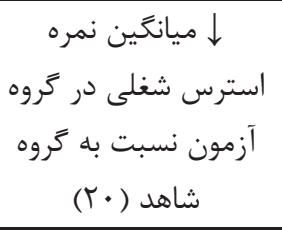 & تافترس إندس شغلى & 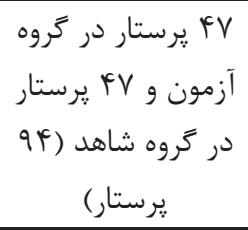 & در دسترس و & $\begin{array}{c}\text { تأثير آموزش هوش معنوى كاهش استرس شغلى } \\
\text { يرستاران }\end{array}$ & تجربى دو & 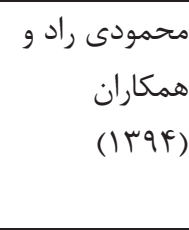 \\
\hline 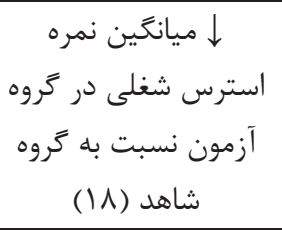 & تافت إترس شنامه & 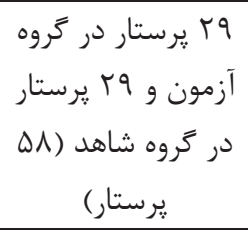 & در دسترس و & كأثير آموزش بهداشت بر & تجربى دو & $\begin{array}{l}\text { همكينى واران } \\
\text { هو (1) }\end{array}$ \\
\hline 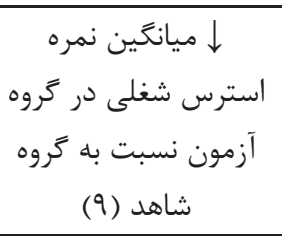 & تافترست اندسم شغلى & 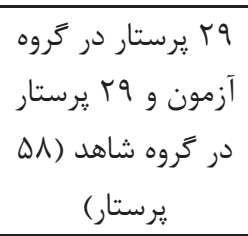 & تر دسترس و & 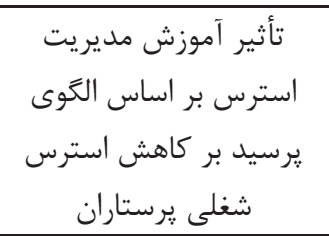 & تجربى دو & همكاران \\
\hline 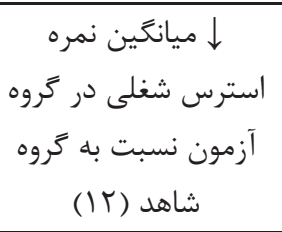 & تافت & 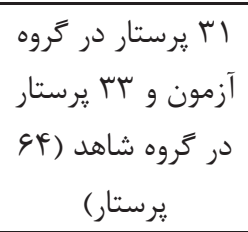 & تصادفى ساده و & كأثير مديريت استرس بر & تجربى دروهى & 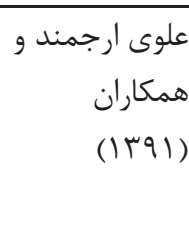 \\
\hline 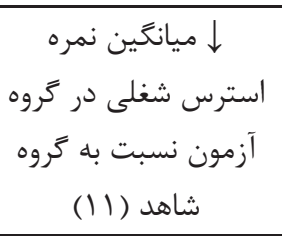 & تافترس إسنامه شغلى & 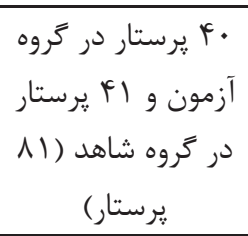 & در دسترس و & التأثير آموزش مبتنى بر & تجربمى دروهى & $\begin{array}{l}\text { ديدهور و هماران } \\
\text { و (1) }\end{array}$ \\
\hline 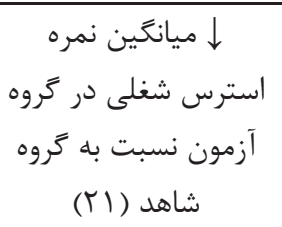 & تافتر إنش اندرس شغلى & 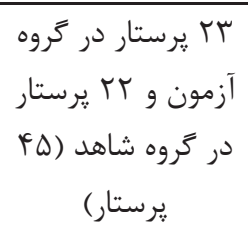 & سرشمارى و & 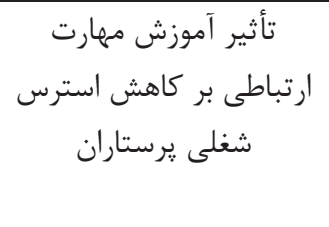 & تجربى نجم دو & 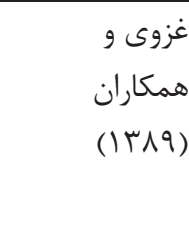 \\
\hline
\end{tabular}

براى بررسى ناهمخنى انجام شد.

\section{نتايج تحليل حساسيت}

در اين بررسى كه با حذف مطالعه خاص اندازه اثر و فاصله اطمينان اندازه اثر مشتر ك رابراى ساير مطالعات بررسى مى كند، نتايج نشان داد كه مطالعات حسينى مقدار اندازه اثر تغيير قابل ملاحظهاى به سمت صفر خواهد داشت (نمودار ب)؛ به عبارت ديگر اين دو مطالعه، باعث بيش برآوردى اندازه اثر در كاهش ميزان استرس به بودند. در كام بعدى با حذف اين مطالعات تحليل مجدد صورت كرفت كه مقدار بيشترين اندازه اثر در كمترين ميزان كاهش بـ استرس توسط اين مداخلات را نشان داد.
بررسى شد. نتايج مقياس ارزيابى كيفيت مقالات در جدول شمارهـ ارائه شده است. با توجه به مقياس ارزيابى كوكران، تنها حيطه تورش ريزش در مطالعات منتخب به صورت خطر سوگيرى يايين ززارش شده بود و حيطههاى تورش :ننهانسازى تصادفى، كورسازى نمونه، كورسازى ييامد، تزارش و انواع تورش در مطالعات

منتخب به صورت نامشخص ززارش شده بودند (جدول ؟). نتايج كلى بررسى مطالعات نهايى شده به صورت Forest Plot ارائه

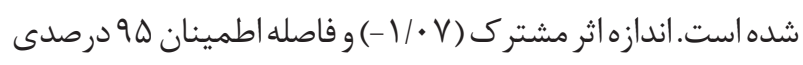
آن (اله|•-- تا سع/| -) حاكى از اثر كاهشى مداخلات بر استرس

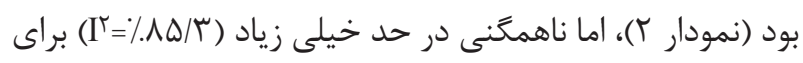
اين مطالعات وجود داشت؛ به همين دليل در ادامه، تحليلهايى 
جدول ب- ارزيابى كيفيت مقالات با استفاده از مقياس Cochrane Risk of Bias Tool

\begin{tabular}{|c|c|c|c|c|c|c|c|}
\hline \multicolumn{7}{|c|}{ مقياس Cochrane Risk of Bias Tool (انواع تورش) } & \multirow[b]{3}{*}{ نويسندكًان (سال) } \\
\hline \multirow[b]{2}{*}{ ساير انواع } & \multirow[b]{2}{*}{ تورش ريزش } & \multirow[b]{2}{*}{ توزارش تورش } & \multicolumn{2}{|c|}{ تورش عملكرد } & \multicolumn{2}{|c|}{ 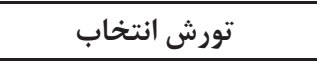 } & \\
\hline & & & كورسازى & كورسازى & تصنهانسازى تصادفى & تواليد توادفى & \\
\hline نامشخص & يايين & نامشخص & نامشخص & نامشخص & نامشخص & بالا & 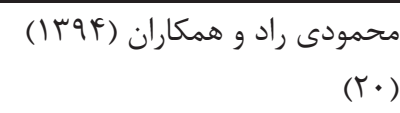 \\
\hline نامشخص & 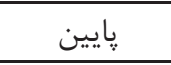 & نامشخص & نامشخص & نامشخص & نامشخص & بالا & حسينى و همكاران (l) (1) (1) (1) \\
\hline 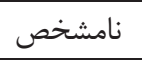 & 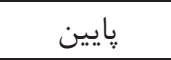 & 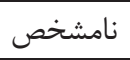 & 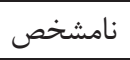 & نامشخص & نامشخص & 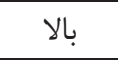 & 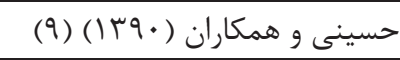 \\
\hline 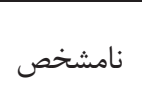 & 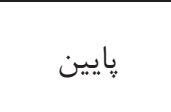 & ن نامشخص & 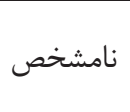 & 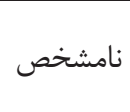 & ن ن امشخص & 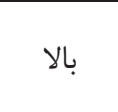 & علوى ارجمند و همكاران ( I I I I ) \\
\hline ن نامشخص & 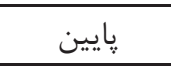 & نامشخص & نامشخص & نامشخص & نامشخص & 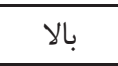 & ديدهور و همكاران (f (I) (I) (1) \\
\hline نامشخص & 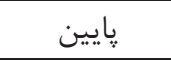 & ن ن امشخص & ن ن امشخص & نامشخص & نامشخص & 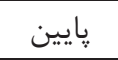 & 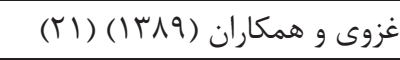 \\
\hline
\end{tabular}

نتايج بعد از حذف مطالعات با اندازه اثر دورافتاده

نتايج اين بررسى در قالب تحليل حساسيت نشان داد كه با حذف بـ مدان مطالعات دورافتاده، ناهمخنى در مطالعات به حد صد صفر رسئ رسيد

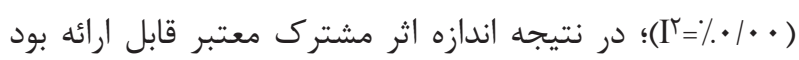

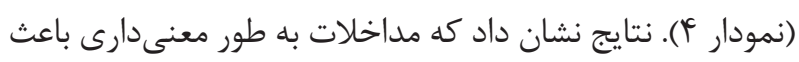

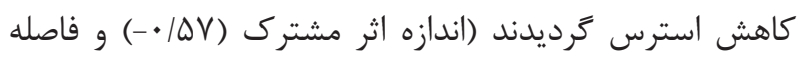

نتايج متاركرسيون نتايج متاركرسيون نشان داد كه هيجيك از متغيرهاى سال مطالعه،

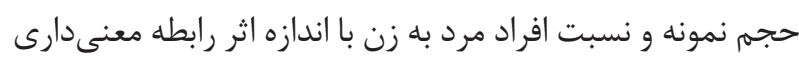
نداشتند (ه • P> (P) و در نتيجه علت ناهمكنى اين متغير ها نبودند (جدول f).
Study

ID

$\%$
$\operatorname{SMD}(95 \% \mathrm{CI}) \quad$ Weight

$-0.47(-0.88,-0.06) \quad 17.89$

$-1.97(-2.60,-1.34) \quad 15.81$

$-2.10(-2.75,-1.46) \quad 15.67$

$-0.68(-1.19,-0.18) \quad 17.05$

$-0.42(-0.86,0.02) \quad 17.63$

$-0.95(-1.57,-0.33) \quad 15.94$

$-1.07(-1.63,-0.51) \quad 100.00$

$(-3.02,0.88)$ 


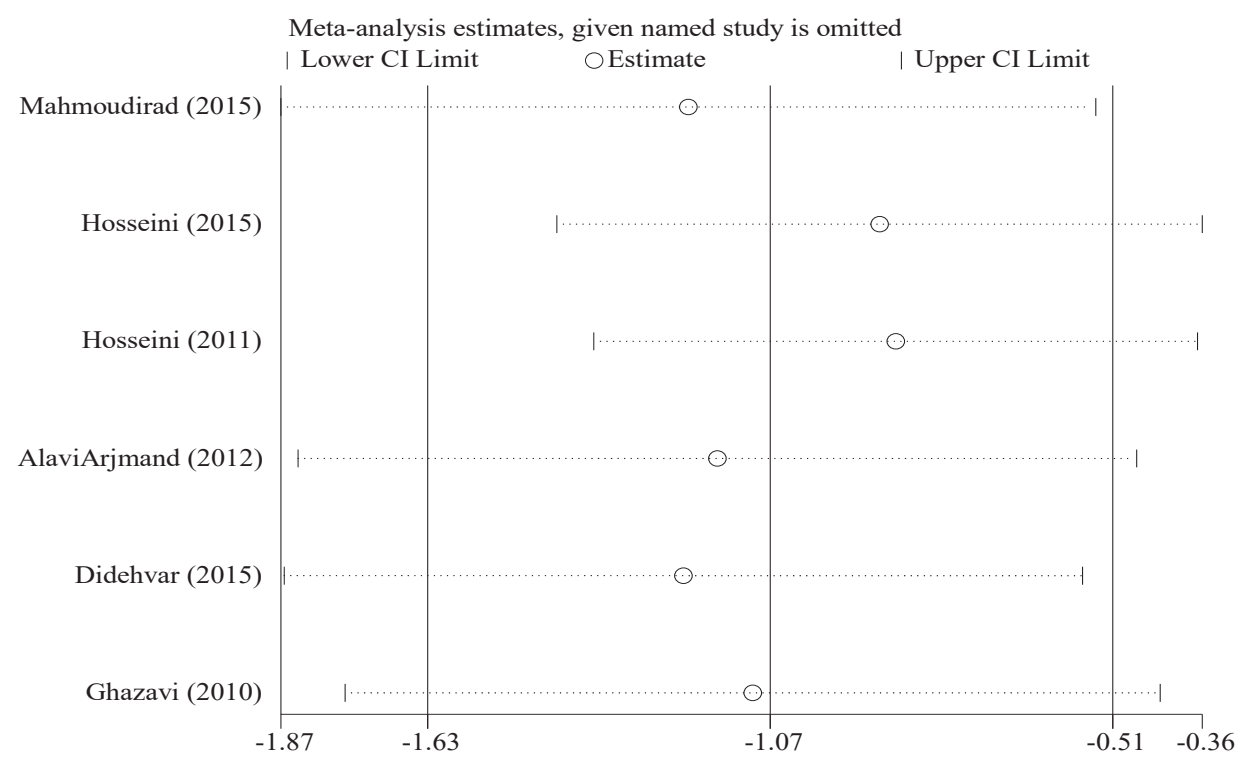

نمودار بـ- نمودار تحليل حساسيت اندازه اثر و فاصله اطمينان هو درصدى مداخلات در كاهش استرس با حذف هر يك از مطالعات

جدول F - م- نتايج متاركر سيون در بر رسى عوامل ناهمكنى

\begin{tabular}{|c|c|c|c|c|}
\hline مقدار معنى دارى & حد بالاى فاصله اطمينان & حد يايين فاصله اطمينان & ضريب رَرسيون & متغيرها \\
\hline$\cdot / \vee 9 \Delta$ & r/TrA & $-r / \Delta \cdot \Lambda$ & $-\cdot \cdot 1 \cdot 9$ & سال مطالعه \\
\hline$\cdot|r q|$ & $\cdot / V \cdot 9$ & $-\cdot \mid \Delta \Phi V$. & $\cdot 1 \cdot V_{1}$ & حجم نمونه \\
\hline 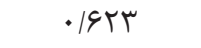 & T/THו & 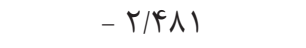 & $-\cdot / 1 T \Delta$ & نسبت تعداد مردان به زنان \\
\hline
\end{tabular}

$F(r, 1)=1 / * \varphi, P=* / 9 \cdot 1$

Study

ID

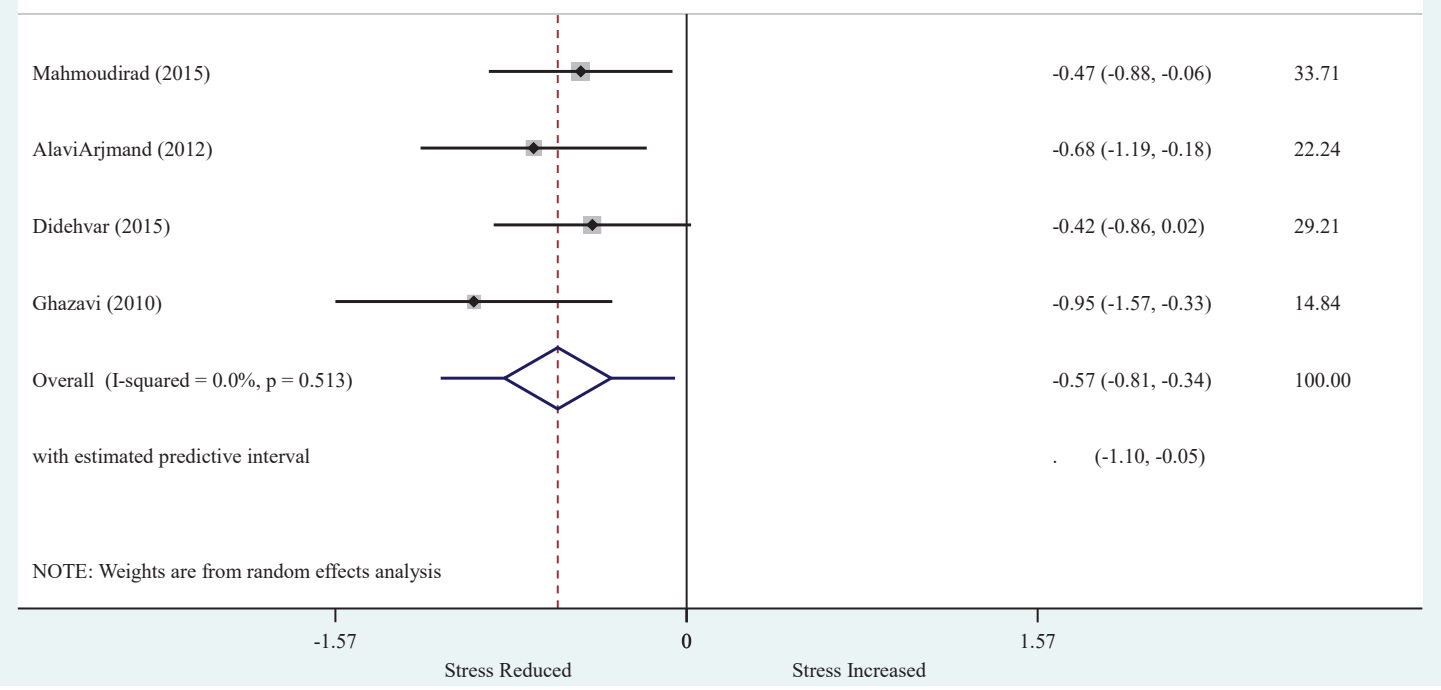

نمودار Forest - ن نمودار اندازه اثر و فاصله اطمينان هو درصدى مداخلات در كاهش استرس شغلى يرستار ان با حذف مطالعات دورافتاده

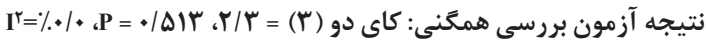

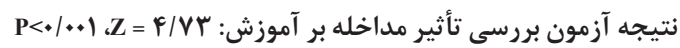




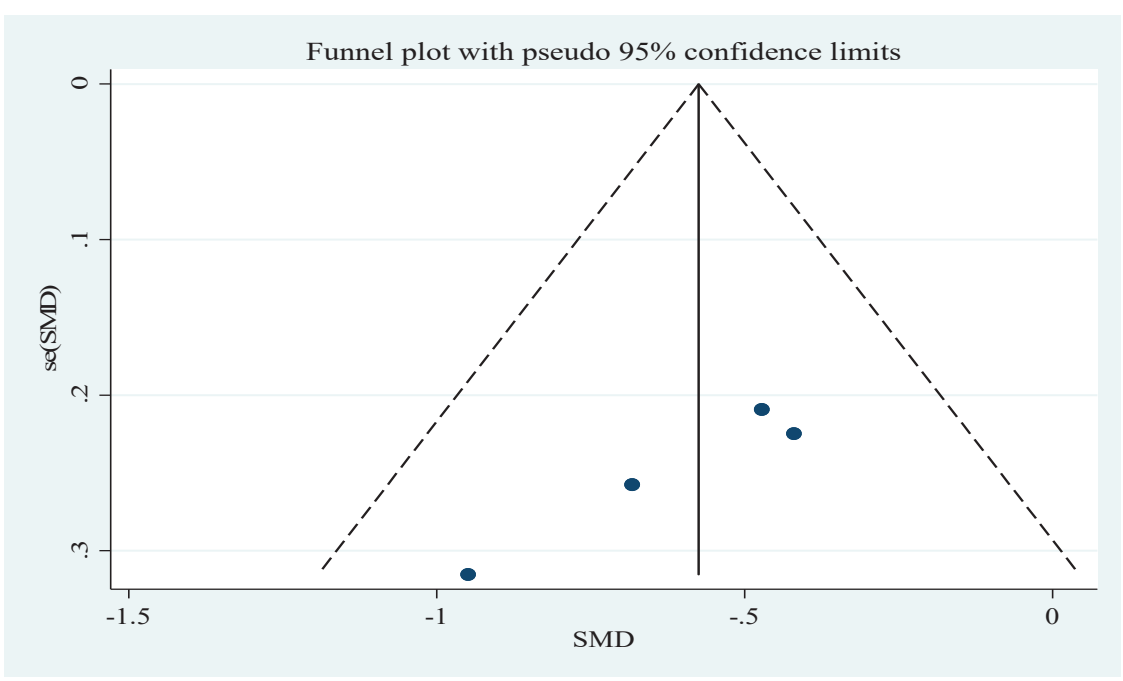

نمودار هـ- نمودار قيفى اندازه اثر در مقابل خطاى معيار اندازه اثر براى بررسى اريبى انتشار

سيس اجتناب محور بود (Tr). (T)

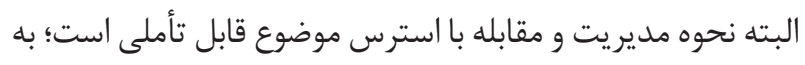

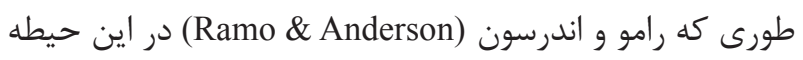

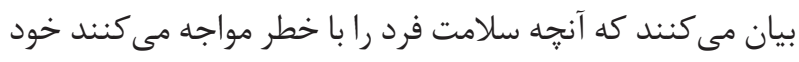

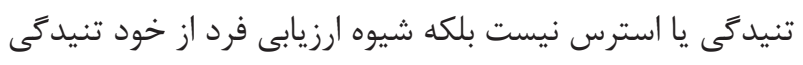

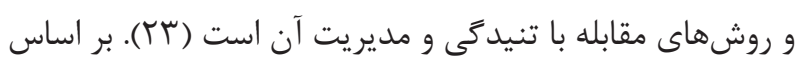
الكَى كنش متقابل در استرس، تصورى كه فرد از منابع موجود و

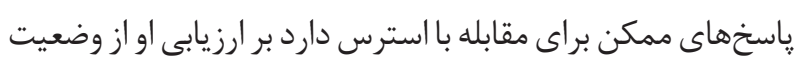

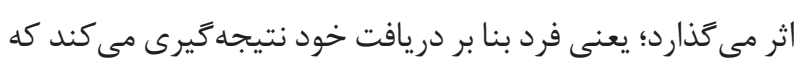

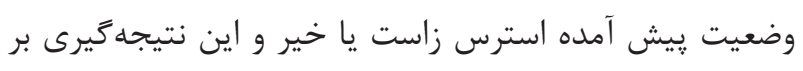

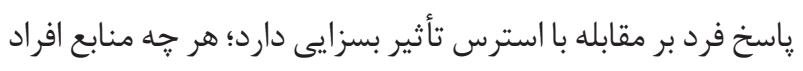
براى مقابله بيشتر باشد، كمتر اين احتمال وجود دارد تا كرفتار

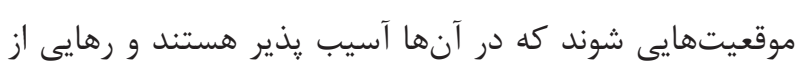

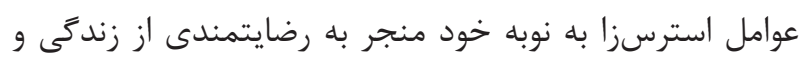
به ويزه رضايت شغلى به عنوان يكى از مؤلفههاى تعيين كننده

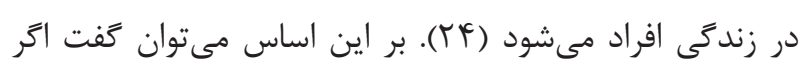

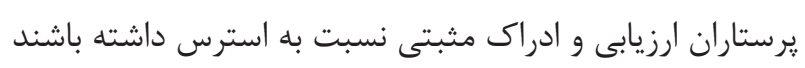

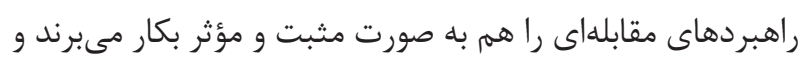

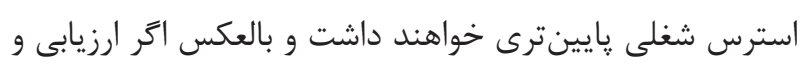
ادراك منفى نسبت به استرس داشته باشند در انتخاب و بكاركيرى

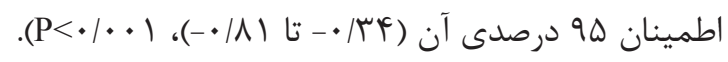
بر رسى اريبى انتشار نمودار قيفى (نمودار ه)، با حضور نقاط در دو طرف اين دو نمودار،

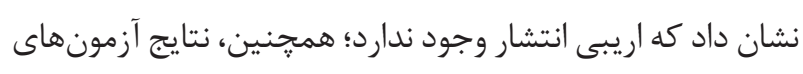

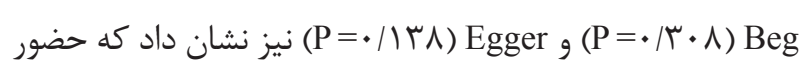

$$
\text { اريبى انتشار معنى دار نبود. }
$$

\section{بحث و نتيجهلَيرى}

مطالعه حاضر با هدف تأثير آموزش مقابله با استرس بر استرس نترى

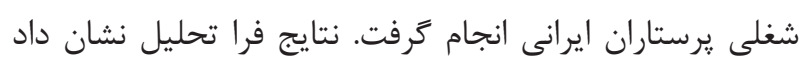
كه مداخلات آموزشى مديريت استرس بر كاهش استرس شغلى إنى

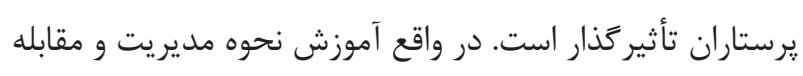

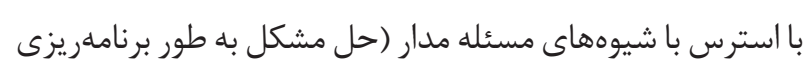

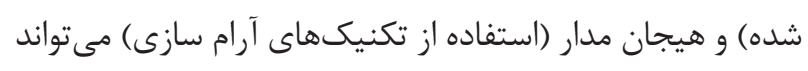

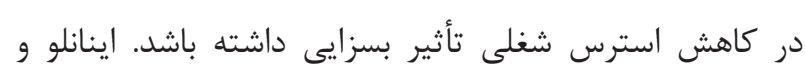

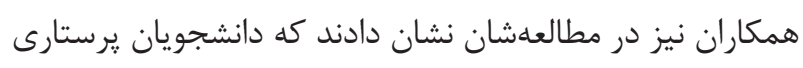

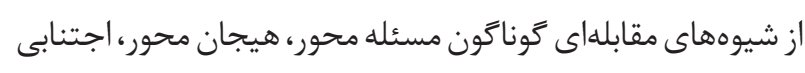

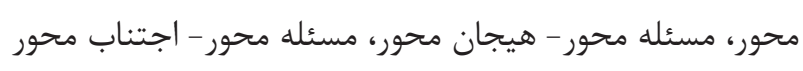

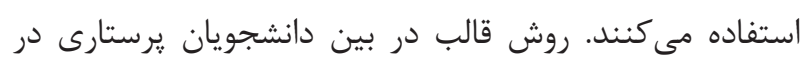

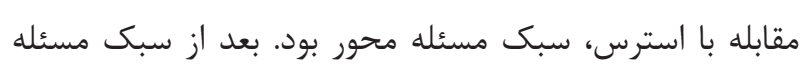

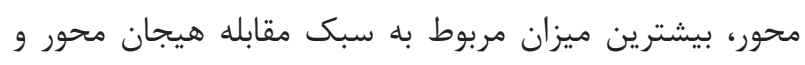


ارجحيت دادهاند؛ به طورى كه صفايى يور و عارفى در مطالعهاى

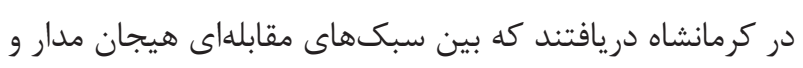

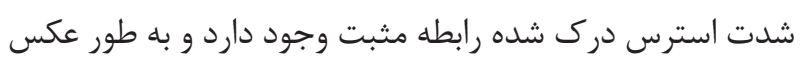

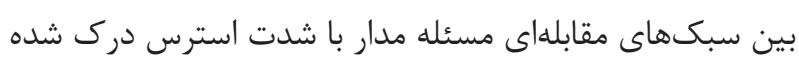

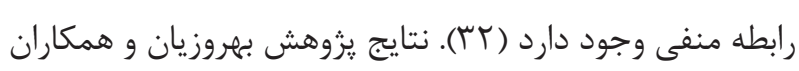
نيز نشان داد افرادى كه از شيوههاى مقابلهاى متمر كز بر حلى حل مسئله استفاده مى كنند، رضايت شغلى و سلامت عمومى بالايى دارند

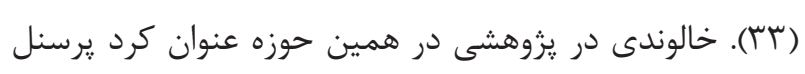
بيمارستانى كه از شيوههاى مقابلهاى مسئله مدار استفاده مى كردن درند

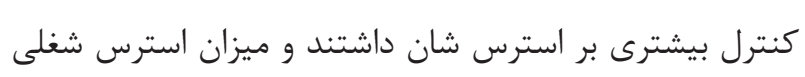

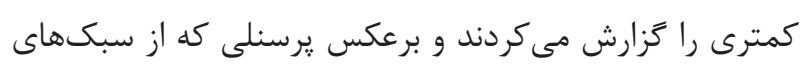

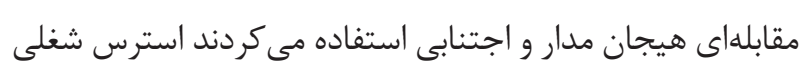
بيشترى را داشتند (YY) (T). از نظر لازاروس و فولكمن نيز لافرادى كه از راهبرد مسئله محور

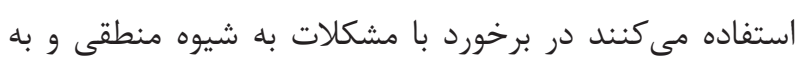

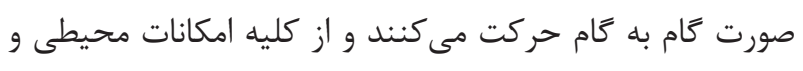

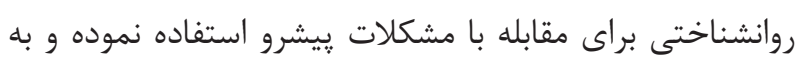

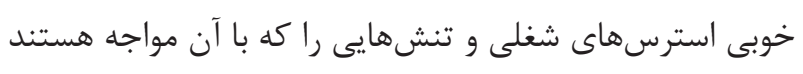

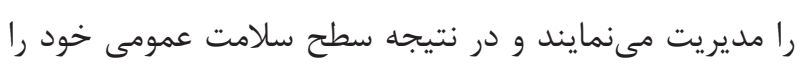

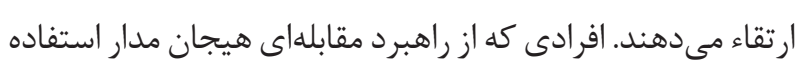

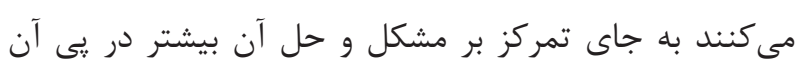
هستند تا هيجانات منفى ناشى از عامل استرسزا رأ را مهار نمايند. راهبردهاى هيجان مدار در كوتاه مدت براى كاهش تنش أنش مؤثر

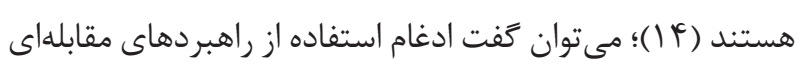

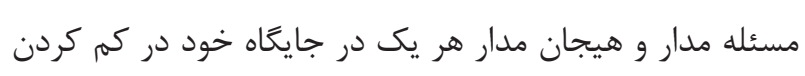
استرس شغلى يرستاران تأثير كذار است.

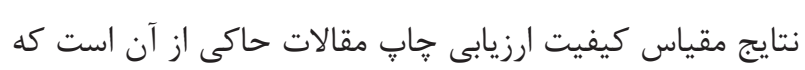

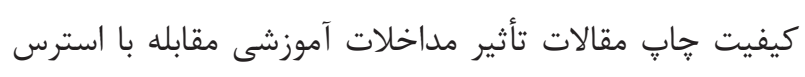

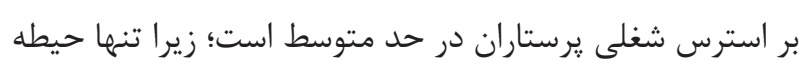
تورش ريزش در مطالعات منتخب به صورت خطر سو گيرى پايين كَزارش شده بود و ساير حيطههاى تورش (ينهانسازى تصادفى، كورسازى نمونه، كورسازى ييامد، كزارش و انواع تورش در مط مطالعات

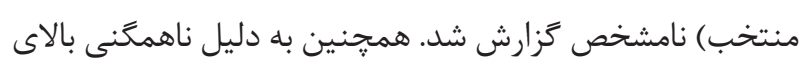

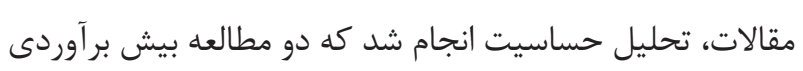

مرور نظاممند و فرا تحليل حاضر در ميان گرستاران استانهاى مختلف ايران و با طيفهاى سنى كوناكون انجام شد و نتايج مشابهى در بر داشت؛ بر اساس شواهد مكانيسمهاى مقابله با بان

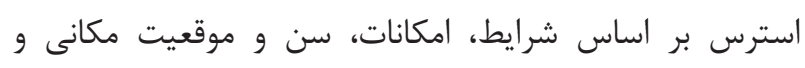

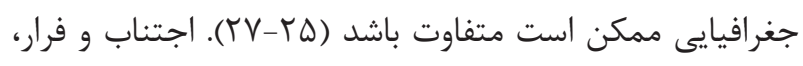
انكار و دورى كزينى براى مقابله با شرايط عاطفى مورد استفادي ماده

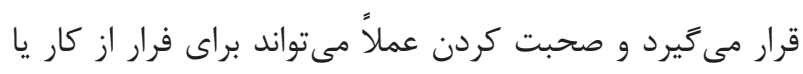

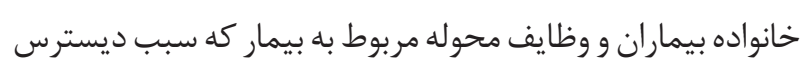

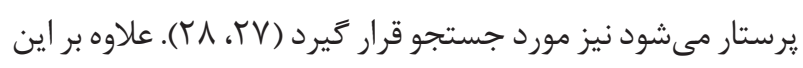

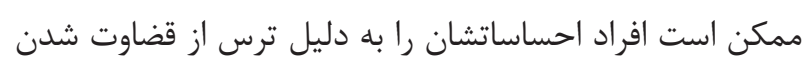

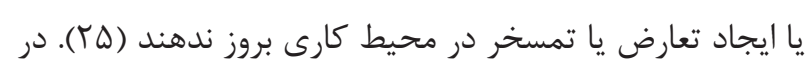

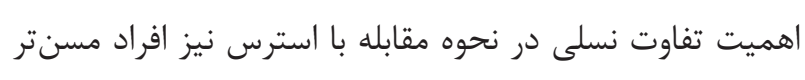

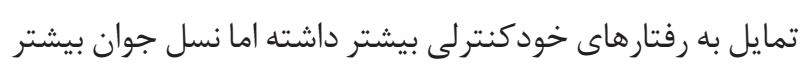

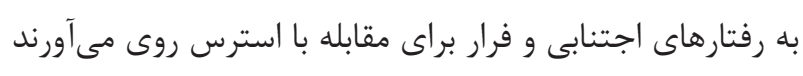

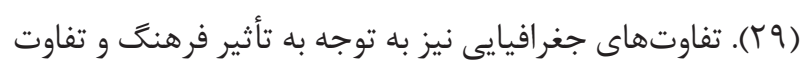
سيستمهاى مراقبت بهداشتى مى تواند در واكنش مقابلهاى افراد

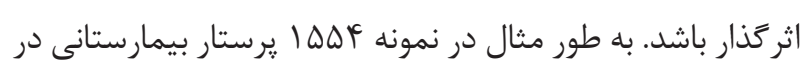

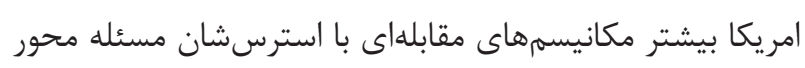

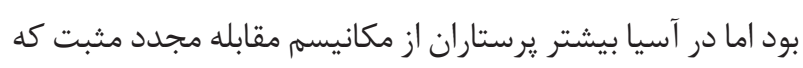

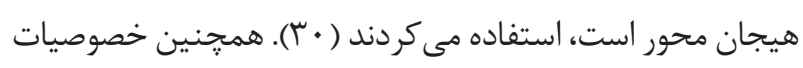

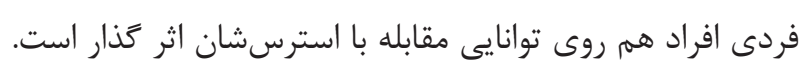
مى توان كفت ويزگى هاى فردى و زمينهاى كار كنان و درى ارى ارتباط

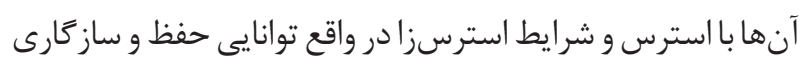
با استرسورهاى Stressors محيطى را در بر مى گيرد ( آس). با توجه

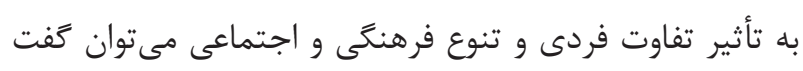

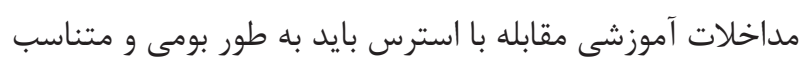
با جوامع مختلف هدف زَزارى و طراحى شود.

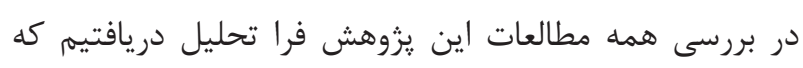
انواع مداخلات آموزشى با تكيه بر دو راهبرد مقابله مسئله مدار

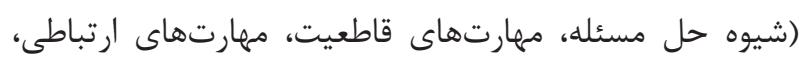

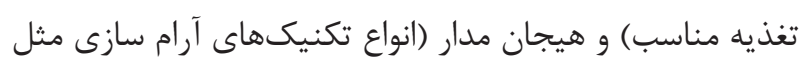

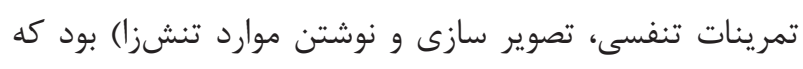

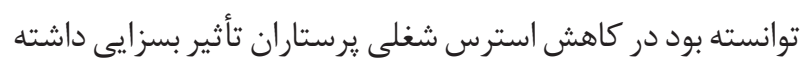

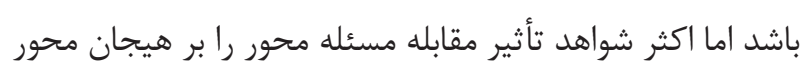


انجام يزوهشهاى بدون تورش و معتبر و كزارش دقيق آنها

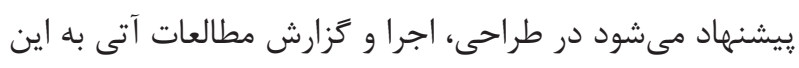

$$
\text { مهمم نيز توجه جدى شود. }
$$

\section{تشكر و قدردانى}

تيم تحقيق از همكارى روششناسى و لوجستيكى مركز تحقيقات

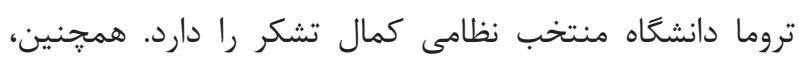

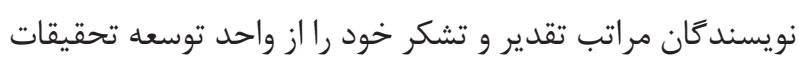

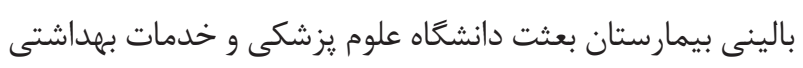

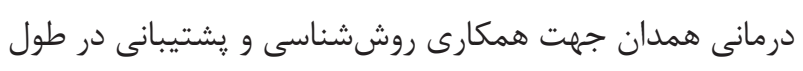
دوره مطالعه اعلام مى دارند.

تضاد منافع

بدين وسيله نويسندكان تصريح مى كنند كه هيج كونه تضاد منافعى در خصوص يزوهش حاضر وجود ندارد.

\section{References}

1- Torshizi M, Saadatjoo A. Job stress in the staff of a tire factory. J of Birjand Univ of Med Sci 2012;19(2):200-7.

2- Carlson D, Kacmar K, Williams L. Construction and Initial Validation of a Multidimensional Measure of Work-Family Conflict. J Vocation Behav. 2000;56(2):249-76. http://dx.doi. org/10.1006/jvbe.1999.1713

3- Mohammadi S, Haghighi S. Relation between job stress and burnout among nursing staff. Sci J of Hamadan Nurs \& Midwifery Fac. 2011;19(2):42-52.

4- Epstein R, Rubinfeld D. Understanding UPP. The BE Journal of Theoretical Economics. 2010;10(1). http://dx.doi. org/10.2202/1935-1704.1641

5- Yang Y, Kim J. A Literature Review of Compassion Fatigue in Nursing. Korean J Adult Nurs. 2012;24(1):38-51. http://dx.doi. org/10.7475/kjan.2012.24.1.38

6- Bianchi ER. Stress and coping among cardiovascular nurses: a survey in Brazil. Issues Ment Health Nurs. 2004;25(7):737-45. http://dx.doi.org/10.1080/01612840490486818 www.ncbi.nlm. nih.gov/pubmed/15371140

7- Mehrabi T, Parvin N, Yazdani M, Asemanrafat N. Investigation of some occupational stressors among nurses. Iranian J of Nurs and Midwifery Res. 2010;10(2):43-55.

8- Ghasemi S, Attar M. Investigation intensity of nurses occupational stressors at Babol, Sari. Behshahr Betsa. 2008;2(1):1-7.

9- Hosseini Z, Moeini B, Hazavehei S, Aghamollai T, Moghimbeigi A. Effect of educational stress management, based on Precede
اندازه اثر داشت كه با حذف اين دو مطالعه در تحليل مجدد مقدار اندازه اثر در كمترين ميزان كاهش استرس توسط اين مداخلات

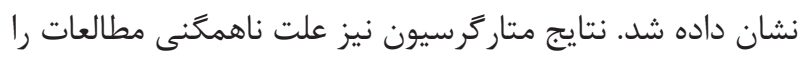
دخالت متغيرهاى سال مطالعه؛ تعداد نمونه و نسبت مرد به زن نشان نداد؛ بنابراين با حذف مطالعات با اثر دور افتاده همخنى صورت يذيرفت و در نتيجه اندازه اثر مشترك معتبر ارائه شد. محدوديت اجراى اين مطالعه شامل عدم دسترسى به دادههاى لازم بود در واقع تعدادى از مقالات جمعآورى شده دادهاى مرتبط با مطالعه حاضر را يوشش نداده بودند و يا شكل ارائه دادههايشان به نوع خاصى همانند فراوانى و درصد فراوانى بود كه امكان ادغام آنها در فرا تحليل مهيا نبود.

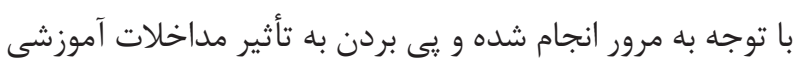
مقابله سازگار و كارآمد با استرس بر استرس شغلى : يرستاران مىتوان به برنامهريزى اجرايى اين مداخلات آموزشى در جهت كاهش استرس شغلى يرستاران همت گمارد. با عنايت به اهميت

model, on job stress of nurses. Bimonthly J of Hormozgan Univ of Med Sci. 2011;15(3):200-8.

10- Sheykhi M, Sarichlou M, Javadi A, Moradi M. Effect of nurses empowerment on coping with job stresses. J Qazvin Univ Med Sci 2009;12(4):38-42.

11- Didehvar M, Jalili Z, Zareban I, Shahrakipour M, Bakhshani N. The Effect of Stress Management Education Based on PRECEDE Model on Occupational Stress of Nurses in Hospitals of Iranshahr Iran. Strides in Development of Med Edu J. 2015;12(3):472-84.

12- Alavi Arjmand N, Kashaninia Z, Hosseini M, Rezasoltani P. Effect of stress management on job stress and work-family conflict among nurses. Hayat. 2013;18(4):81-91.

13- Kravits K, McAllister-Black R, Grant M, Kirk C. Self-care strategies for nurses: A psycho-educational intervention for stress reduction and the prevention of burnout. Appl Nurs Res. 2010;23(3):130-8. http://dx.doi.org/10.1016/j.apnr.2008.08.002 www.ncbi.nlm.nih.gov/pubmed/20643322

14- Lazarus R, Folkman S. Stress, appraisal. and coping New York, NY. Springer Publishing Company. 1984.

15- Kleink KE. Life skills. First ed. Tehran: Publications of Espande Honar; 2002.

16- Vahedian-Azimi A, Hajiesmaeili M, Kangasniemi M, FornesVives J, Hunsucker RL, Rahimibashar F, et al. Effects of Stress on Critical Care Nurses: A National Cross-Sectional Study. J Intensive Care Med. 2019;34(4):311-22. http://dx.doi. org/10.1177/0885066617696853 www.ncbi.nlm.nih.gov/ 
pubmed/29277137

17- Grzywacz JG, Frone MR, Brewer CS, Kovner CT. Quantifying work-family conflict among registered nurses. Res Nurs Health. 2006;29(5):414-26. http://dx.doi.org/10.1002/nur.20133 www. ncbi.nlm.nih.gov/pubmed/16977647

18- Hosseini Z, Aghamollai T, Moeini B. The effect of health education program on femail nursses stress. Health System Res 2015;11(1):43-52.

19- Higgins J, Green S. Cochrane handbook for systematic reviews of interventions: John Wiley \& Sons; 2011.

20- Mahmoudirad G, Bagherian F. Effects of spiritual intelligence training on nurses'job stress. Quarterly J of Nurs Management 2015;4(1):69-79.

21- Ghazavi Z, Lohrasbi F, Mehrabi T. Effect of communication skill training using group psychoeducation method on the stress level of psychiatry ward nurses. Iran J Nurs Midwifery Res. 2010;15(Suppl 1):395-400. www.ncbi.nlm.nih.gov/pubmed/22069416

22- Inanloo M, Baha R, Seyedfatemi N, Hosseini A. Stress coping styles among nursing students. Hayat. 2012;18(3):66-75.

23- Anderson KG, Ramo DE, Brown SA. Life stress, coping and comorbid youth: an examination of the stress-vulnerability model for substance relapse. J Psychoactive Drugs. 2006;38(3):255-62. http://dx.doi.org/10.1080/02791072.2006.10399851 www.ncbi. nlm.nih.gov/pubmed/17165368

24- Jafary E, Kamarzarin H, Kordmirza E, Sefizadeh V. The role of spiritual well-being and coping skills in prediction of job satisfaction in nurses. $J$ of Clinical Nurs and Midwifery 2015;4(3):50-8.

25- Jannati Y, Mohammadi R, Seyedfatemi N. Iranian clinical nurses' coping strategies for job stress. J Occup Health. 2011;53(2):1239. http://dx.doi.org/10.1539/joh.o10015 www.ncbi.nlm.nih.gov/ pubmed/21245651

26- Wakim N. Occupational stressors, stress perception levels, and coping styles of medical surgical RNs: a generational perspective. J Nurs Adm. 2014;44(12):632-9. http://dx.doi. org/10.1097/NNA.0000000000000140 www.ncbi.nlm.nih.gov/ pubmed/25393139

27- Su SF, Boore J, Jenkins M, Liu PE, Yang MJ. Nurses' perceptions of environmental pressures in relation to their occupational stress. J Clin Nurs. 2009;18(22):3172-80. http://dx.doi.org/10.1111/j.13652702.2008.02771.x www.ncbi.nlm.nih.gov/pubmed/19538558

28- Li J, Lambert VA. Workplace stressors, coping, demographics and job satisfaction in Chinese intensive care nurses. Nurs Crit Care. 2008;13(1):12-24. http://dx.doi.org/10.1111/j.14785153.2007.00252.x www.ncbi.nlm.nih.gov/pubmed/18226051

29- Lambert VA, Lambert CE, Itano J, Inouye J, Kim S, Kuniviktikul W, et al. Cross-cultural comparison of workplace stressors, ways of coping and demographic characteristics as predictors of physical and mental health among hospital nurses in Japan, Thailand, South Korea and the USA (Hawaii). Int J Nurs Stud. 2004;41(6):671-84. http://dx.doi.org/10.1016/j.ijnurstu.2004.02.003 www.ncbi.nlm. nih.gov/pubmed/15240091

30- Hays MA, All AC, Mannahan C, Cuaderes E, Wallace D. Reported stressors and ways of coping utilized by intensive care unit nurses. Dimens Crit Care Nurs. 2006;25(4):185-93. http://dx.doi. org/10.1097/00003465-200607000-00016 www.ncbi.nlm.nih. gov/pubmed/16868472

31- Hashemian S, Farzanegan B, Fathi M, Ardehali S, Vahedian-Azimi A, Asghari-Jafarabadi M, et al. Stress Among Iranian Nurses in Critical Wards. Iranian Red Crescent Med J. 2015;17(6). http:// dx.doi.org/10.5812/ircmj.22612v2

32- Safaee P, Arefi M. The relation between coping styles and perceived stress in nurses of educational hospitals in kermanshah university of medical sciences. J of Clinical Res in Paramedical Sci 2015;4(1):34-42.

33- Behrouzian F, Khajeddin N, Hodaei F, Zamani N. The relationship of job satisfaction and coping mechanism with general health, among private industrial's staff. Jundishapur Sci Med J 2009;8(362):345-53.

34- Khalvandi M. Investigte the relationship between job stress and coping styles in Imam Ali hospital personnel Yazd. J of Modern Res. 2011;3(1):13-26. 